\title{
Photoinduced antibacterial activity of two dicationic 5,15-diarylporphyrins
}

\author{
Viviana T. Orlandi ${ }^{\text {a,* }}$, Enrico Caruso ${ }^{\text {a }}$, Gianluca Tettamanti ${ }^{\mathrm{b}}$, Stefano Banfi ${ }^{\mathrm{a}}$, Paola Barbieri ${ }^{\mathrm{a}}$ \\ a Department of Theoretical and Applied Sciences, University of Insubria, Via J.H. Dunant, 3, 21100 Varese, Italy \\ ${ }^{\mathrm{b}}$ Department of Biotechnology and Life Sciences, University of Insubria, Via J.H. Dunant, 3, 21100 Varese, Italy
}

\section{A R T I C L E I N F O}

\section{Article history:}

Received 17 April 2013

Received in revised form 12 July 2013

Accepted 19 August 2013

Available online 28 August 2013

\section{Keywords:}

5,15-Dipyridylporphyrins

Photodynamic treatment

Dicationic photosensitizers

\begin{abstract}
A B S T R A C T
Antimicrobial photodynamic treatment combines the use of photosensitizers (PSs) and visible light to kill bacterial cells. Cationic porphyrins are PSs largely used against bacteria and, among them, those featuring one positive charge on each of the 5,10,15,20-tetraaryl substituent (tetracationic) are the most used. The aim of this study was to synthesize two dicationic 5,15-di(N-alkyl-4-pyridyl)porphyrins, bearing methyl (PS 3) and benzyl (PS 4) N-alkylating groups, and to compare the efficiency in antibacterial photodynamic treatment, upon irradiation with a halogen-tungsten white lamp.

The killing efficiency of the PS 4 was constantly found higher than that of the PS 3 against both pure and mixed cultures of laboratory model microorganisms as well as against wild wastewater microflora. The two PSs are comparable as regards singlet oxygen generation, but show a different repartition coefficient; the more lipophilic benzylated PS $\mathbf{4}$ shows a better interaction with the bacterial cells than the methylated one (PS 3). The data support the hypothesis that an efficient PS-cell binding is required to obtain significant effects. A correlation among cell binding, photoinactivation and PS lipophilicity is suggested.
\end{abstract}

(c) 2013 Elsevier B.V. All rights reserved.

\section{Introduction}

The control of microorganism growth is a relevant topic in several contexts and can be achieved by means of chemical or physical agents or by their simultaneous combination. A disinfection system based on the photodynamic approach could potentially be applied to distinct needs. This approach requires the concomitant application of a chemical compound, the photosensitizer (PS), and of a visible light characterized by a suitable energy and wavelength of emission able to excite the PS. The PS, bound to the target cells and excited by light irradiation, transfers the adsorbed energy to any molecule present in the close proximity $(<0.02 \mathrm{~mm})$ [1]. When this energy transfer process involves molecular oxygen, singlet oxygen $\left({ }^{1} \mathrm{O}_{2}\right)$ and/or reactive oxygen species (ROS) become the final products. Both these oxidizing species react with most biological molecules thus inducing damages to most of the cell structures finally leading to cell death [2]. The PSs used to this end are substantially dyes which share, as common feature, the presence of a large number of conjugated double bonds thus allowing the interaction of the $\pi$ electrons with low energy radiations i.e. the visible light.

\footnotetext{
* Corresponding author. Tel.: +39 0332 421438; fax: +39 0332421330 .

E-mail address: viviana.orlandi@uninsubria.it (V.T. Orlandi).
}

Among the several classes of known PSs, encompassing both natural and synthetic compounds, cyclic tetrapyrrolic derivatives, including porphyrins and the reduced congeners (chlorines and bacteriochlorines), benzoporphyrins and their aza analogoues phthalocyanines, have been widely studied as they constitute a particularly versatile basic frame to design new PSs [3]. Such versatility accounts for the possible synthesis of differently structured molecules on the base of the specific characteristics needed for cell interactions, as prokaryotes and eukaryotes feature very different envelopes. Actually various PSs can be used for the photoinactivation of prokaryotes, however the efficacy of a given PS can dramatically differ when the target is a Gram positive or Gram negative bacterium [4]. Indeed, it is well known that Gram negative bacteria are more resistant to the photodynamic action than Gram positive. This has been ascribed to the presence of the structurally complex outer membrane the Gram negative are endowed with [5]. To improve the efficiency of PS against Gram negative two features are thought to be important: (1) the presence of positive charges on the PS, that promote a tight interaction with the negative charges of the LPS of the outer membrane [6], and (2) a degree of lipofilicity giving a $\log P>0.5$ thus favouring the interaction with the outer membrane [7].

Porphyrins display peculiar PS structural characteristics that can be easily achieved tuning the reagents used in their synthesis, which is generally based on an acid catalyzed condensation of 
aromatic aldehydes with pyrrole. Furthermore, as all the porphyrins are characterized by a wide-range absorption spectrum extended from the blue Soret band to the green and red $\mathrm{Q}$ bands, these PSs might be used in the presence of broad band emitting light sources, including sunlight. This characteristic of the porphyrin skeleton makes these PSs also suitable for the treatment of different matrixes contaminated by bacteria. As an example these PS could be used for the disinfection of microbiologically polluted waters $[8,9]$.

Tetracationic tetraarylporphyrins, such as the commercial tetra(N-methyl-4-pyridyl)porphyrin tetratosylated and the tetra(4trimethylammonium-phenyl)porphyrin tetraiodide and some of their congeners, have been widely studied in the photodynamic antimicrobial chemotherapy (PACT) [10-12]. From these studies the presence of four ammonium groups (one for each meso aromatic moiety) appears to be a mandatory requirement to achieve an efficient antimicrobial activity, although some activity has been also reported for three-cationic tetraarylporphyrins [13]. The 5,15diarylporphyrins featuring two positive charges are expected to be less hydrophilic than the tetracationic congeners and, to the best of our knowledge, no studies on the efficacy of such compounds against bacterial cells has been yet reported, although recently in vitro anticancer PDT studies have shown a greater efficacy of the diarylporphyrins with respect to the tetraaryl congeners [14].

Here, the comparison of two dicationic 5,15-diarylporphyrins in the photoinactivation of representative Gram positive and Gram negative bacteria is reported. The disinfection potential of the most efficient dicationic porphyrin was also investigated, using sun light as light source, on small volumes of secondary treated wastewater samples, regarded as model of a matrix highly contaminated by a complex bacterial community.

\section{Materials and methods}

\subsection{General}

UV-vis absorption spectra were measured on a Varian Cary 50 Scan instrument. ${ }^{1} \mathrm{H}$ NMR spectra were recorded on a Bruker $400 \mathrm{MHz}$ spectrometer in $\mathrm{CDCl}_{3}$ or $\left[d_{6}\right.$ ] DMSO; chemical shifts are expressed in ppm relative to chloroform (7.28) and are reported as $\mathrm{s}$ (singlet), $\mathrm{d}$ (doublet), $\mathrm{t}$ (triplet), $\mathrm{m}$ (multiplet), bs (broad singlet). Elemental analyses were performed on a ThermoQuest NA $2100, \mathrm{C}, \mathrm{H}, \mathrm{N}$ analyzer, equipped with an electronic mass flow control and thermal conductivity detector. Fluka F254 silica gel RP-18 ( $0.2 \mathrm{~mm}$ thick) were used for analytical thin-layer chromatography (TLC). Silica gel 60 (70-230 mesh, Merck) was used for column chromatography. Benzyl chloride and methyl iodide were commercial products (Sigma-Aldrich) and used as received. The fluence rate (irradiance, $\mathrm{W} / \mathrm{m}^{2}$ or $\mathrm{mW} / \mathrm{cm}^{2}$ ) was determined with a LI-COR 1800 spectroradiometer. The illuminance of sunlight was measured with a Lux meter LX-101.

The compounds 5-(4-pyridyl)-dipyrrolylmethane (1) and 5,15Dipyridylporphyrin (2) were synthesized according to the method described by Gryko and Lindsey [15] and Goncalves et al. [16], respectively.

\subsection{Synthesis of the cationic photosensitizers $\mathbf{3}$ and $\mathbf{4}$}

\subsubsection{5,15-Di(N-methyl-4-pyridyl)porphyrin (3)}

To $20 \mathrm{mg}(0.043 \mathrm{mmol})$ of 2 were added $10 \mathrm{~mL}$ of $\mathrm{CH}_{3} \mathrm{I}$ and the solution was kept under stirring and reflux for $48 \mathrm{~h}$, following the reaction outcome by TLC ( $\mathrm{RP}-\mathrm{C} 18, \mathrm{H}_{2} \mathrm{O} / 2$-propanol/acetic acid: 4/4/ $2)$. The desired product was collected by filtration after precipitation induced by the addiction of $30 \mathrm{~mL}$ of $\mathrm{Et}_{2} \mathrm{O}$ to the reaction mixture and on cooling. The solid was thoroughly washed with diethyl ether and treated with a few $\mathrm{mL}$ of water; the insoluble material was eliminated by filtration and $12 \mathrm{mg}(38 \%)$ of the desired product were recovered after lyophilisation. $\mathrm{C}_{32} \mathrm{H}_{26} \mathrm{~N}_{6} \mathrm{I}_{2}, M_{\mathrm{w}}=748.4$. UV-vis $\left(\mathrm{H}_{2} \mathrm{O}\right): 408 \mathrm{~nm}(\varepsilon=24,400), 506 \mathrm{~nm}(\varepsilon=1914), 552 \mathrm{~nm}$ $(\varepsilon=1806), 632 \mathrm{~nm}(\varepsilon=1004) .{ }^{1} \mathrm{H}$ NMR $\left(\mathrm{D}_{2} \mathrm{O}\right) \delta:-3.33(\mathrm{~s}, 2 \mathrm{H})$; $4.73(\mathrm{~s}, 6 \mathrm{H}) ; 9.07(\mathrm{~d}, 4 \mathrm{H}) ; 9.24(\mathrm{~d}, 4 \mathrm{H}) ; 9.48(\mathrm{~d}, 4 \mathrm{H}) ; 9.85(\mathrm{~d}, 4 \mathrm{H})$; 10.84 (s, 2H). Anal. Calc.: C, 51.35\%; H, 3.50\%; N, 11.23\% Found; 51.74\%; H, 3.48\%; N, $11.29 \%$.

\subsubsection{5,15-Di(N-benzyl-4-pyridyl)porphyrin (4)}

Compound 2 ( $20 \mathrm{mg}, 0.043 \mathrm{mmol}$ ) was treated with $15 \mathrm{~mL}$ of benzylchloride. The solution was kept under reflux for $48 \mathrm{~h}$, following the reaction outcome by TLC (RP-C18, $\mathrm{H}_{2} \mathrm{O} / 2$-propanol/acetic acid 4/4/2). The reaction work up, carried out as described above, yielded $15 \mathrm{mg}$ (45\%) of the desired product. $\mathrm{C}_{44} \mathrm{H}_{34} \mathrm{~N}_{6} \mathrm{Cl}_{2}$, $M_{\mathrm{w}}=717.70$. UV-vis $\left(\mathrm{H}_{2} \mathrm{O}\right): \quad 410 \mathrm{~nm} \quad(\varepsilon=51,600), \quad 508 \mathrm{~nm}$ $(\varepsilon=3512), 550 \mathrm{~nm}(\varepsilon=3409), 631 \mathrm{~nm}(\varepsilon=1919) .{ }^{1} \mathrm{H}$ NMR $\left(\mathrm{D}_{2} \mathrm{O}\right)$ $\delta:-3.30(\mathrm{~s}, 2 \mathrm{H}) ; 6.30(\mathrm{~s}, 4 \mathrm{H}) ; 7.60(\mathrm{~m}, 10 \mathrm{H}) ; 9.14(\mathrm{~d}, 4 \mathrm{H}) ; 9.31$ (d, 4H); $9.75(\mathrm{~d}, 4 \mathrm{H}) ; 9.84(\mathrm{~d}, 4 \mathrm{H}) ; 10.84$ (s, 2H). Anal. Calc.: C, 73.64\%; H, 4.77\%; N, 11.71\% Found; 74.01\%; H, 4.81\%; N, $11.63 \%$.

\subsection{Partition coefficient measurements}

1-Octanol/water partition coefficient $(P)$ was determined at $25^{\circ} \mathrm{C}$ mixing equal volumes of pre-equilibrated water (milliQ $3 \mathrm{~mL}$ ) and 1-octanol ( $3 \mathrm{~mL})$ containing a suitable amount of porphyrin. Typically, an aqueous solution of cationic porphyrin ( $\approx 40 \mu \mathrm{M})$ was stirred for $8 \mathrm{~h}$ in the thermostat in the presence of octanol, then aliquots of $200 \mu \mathrm{L}$ of both aqueous and organic phases were diluted with $1.8 \mathrm{~mL}$ of DMF ( $2 \mathrm{~mL}$ of total volume) and the porphyrin final concentration was determined by absorption spectroscopy [17]. Values are expressed as $\log P=\log$ ([porphyrin $]_{\mathrm{o}} /[\text { porphyrin }]_{\mathrm{w}}$ ).

\subsection{Photobleaching measurements}

A $15 \mathrm{~mL}$ solution $50 \mu \mathrm{M}$ of porphyrin in $0.1 \mathrm{M}$ phosphate-buffer (PBS, pH 7.4) was exposed to a $500 \mathrm{~W}$ halogen-tungsten lamp for $2 \mathrm{~h}$, with a light irradiance medium value of $0.12 \mathrm{~mW} / \mathrm{cm}^{2} \mathrm{~nm}$ in the range $380-780 \mathrm{~nm}$. The heat of the lamp was cut off by means of an aqueous filter positioned between the light source and the PS solution thus maintaining the temperature at $37^{\circ} \mathrm{C}$. Samples of $0.4 \mathrm{~mL}$ were collected every $15 \mathrm{~min}$, diluted with $1.6 \mathrm{~mL}$ of PBS and the concentration of the residual PS was spectroscopically measured with the UV-vis instrument The results are reported as percentage of the absorbance measured at specific interval with respect to the value of the initial concentration.

\subsection{Comparative singlet oxygen generation measurements}

An aerated isopropanol solution containing $50 \mu \mathrm{M}$ of 1,3 -diphenylisobenzofuran (DPBF) and $1 \mu \mathrm{M}$ of photosensitizer was prepared and kept in the dark. A $2 \mathrm{~mL}$ sample of this solution was transferred into a cuvette and irradiated from the open top side with green LED (maximum light irradiance $0.125 \mathrm{~mW} / \mathrm{cm}^{2} \mathrm{~nm}$ at $524 \mathrm{~nm}$ ) at room temperature up to a maximum of $30 \mathrm{~min}$. At intervals, the absorbance at $410 \mathrm{~nm}$ was measured. The rate of singlet oxygen production was determined from the reduction in intensity of absorbance recorded over time. A sample of DPBF-isopropanol solution was used as the negative control. In this experiments green LED lamp was used for the irradiation as DPBF, the singlet oxygen scavenger, is very unstable and undergoes self photobleaching when irradiated with blue LED and white halogen lamps. The relative singlet oxygen generation rates for PS $\mathbf{3}$ and PS 4 were determined by using Rose Bengal as a reference PS [18]. 


\subsection{Bacterial strains and culture conditions}

The microorganisms used in this study are opportunistic pathogens representative of Gram negative and Gram positive bacteria. Escherichia coli C1a [19], Enterococcus faecalis ATCC 29212 [20], Pseudomonas aeruginosa PAO1 [21] and Staphylococcus aureus ATCC 25293 (MSSA) [22] are wild type bacteria commonly used as model or control strains. E. coli and E. faecalis are also regarded as indicators of faecal contamination. Bacteria were grown overnight in Luria Bertani (LB) broth [23] under aerobic conditions at $37^{\circ} \mathrm{C}$ and then diluted in M9 minimal medium [24] supplemented with $5 \mathrm{mM}$ glucose to obtain a cell concentration of approx. $10^{7} \mathrm{CFU} /$ $\mathrm{mL}$. Viable counts (expressed as colony forming units per $\mathrm{mL}$, $\mathrm{CFU} / \mathrm{mL}$ ) were estimated by plate count technique: a standard volume $(0.1 \mathrm{~mL})$ of undiluted or serially diluted samples was plated on rich or selective agar medium. LB Agar plates and PCA (Plate Count Agar) plates were incubated for $24 \mathrm{~h}$ at $37^{\circ} \mathrm{C}$ to evaluate the viable cells in pure cultures and the total heterotrophic bacteria in wastewater samples, respectively. Plates of mFC Agar supplemented with $1 \%$ rosolic acid (Difco Laboratories) were incubated for $24 \mathrm{~h}$ at $37^{\circ} \mathrm{C}$ and characteristic blue colonies were counted for faecal coliforms. Plates of KF Agar supplemented with TTC 1\% (Difco Laboratories) were incubated for $48 \mathrm{~h}$ at $37^{\circ} \mathrm{C}$ and characteristic reddish colonies were counted for faecal enterococci.

\subsection{Wastewater samples}

Effluent from a conventional activated sludge plant of a Northern Italy little town, was collected after the sedimentation and used in the photoinactivation experiments. Three wastewater samples were collected in three different days on January/February 2011. The concentrations of faecal coliforms, faecal enterococci and heterotrophic bacteria were determined as described above.

\subsection{Photoinactivation assays}

Aliquots of PS aqueous solutions were added to pure or mixed cultures or to wastewater samples, affording the desired PS concentrations $(1,5$ or $10 \mu \mathrm{M})$. After $1 \mathrm{~h}$ of static incubation at $37^{\circ} \mathrm{C}$ in the dark, the cultures were irradiated with a $500 \mathrm{~W}$ halogentungsten lamp (fluence rate $48 \mathrm{~mW} / \mathrm{cm}^{2}$, considering the $400 \mathrm{~nm}$ of the whole width of the lamp emission spectrum) for $75 \mathrm{~min}$ (energy density $216 \mathrm{~J} / \mathrm{cm}^{2}$ ). The lamp was placed at a distance of $20 \mathrm{~cm}$ above the sample and a $1.5 \mathrm{~cm}$ thick circulating water/glass filter was interposed to avoid overheating. Alternatively, the samples were irradiated by sunlight (with or without a UV filter); in these cases lux values and air temperature $\left({ }^{\circ} \mathrm{C}\right.$ ) were measured. Survivors were quantified using the viable count technique as describe above (limit of detection, $10 \mathrm{CFU} / \mathrm{mL}$ ). A panel of controls was set for each experiment: PS untreated and dark incubated samples (-PS, -light), PS treated and dark incubated samples (+PS, -light), PS untreated and irradiated samples (-PS, +light).

\subsection{Porphyrin cell binding assays}

Bacterial cultures $\left(10^{7} \mathrm{CFU} / \mathrm{mL}\right)$ in $\mathrm{M} 9$ medium supplemented with $5 \mathrm{mM}$ glucose, were incubated at $37^{\circ} \mathrm{C}$ in the dark for $1 \mathrm{~h}$ in the presence of $10 \mu \mathrm{M}$ PS. After this period, the samples were centrifuged $(13,000 \mathrm{rpm}$ for $10 \mathrm{~min})$ and the supernatants were spectrophotometrically analyzed to determine the concentration of the unbound PS: the data were registered in the blue wavelength range at 410 and $408 \mathrm{~nm}$, respectively representing the $\lambda_{\max }$ of absorbance for PS $\mathbf{4}$ and PS $\mathbf{3}$ in the aqueous phase. The pellets were suspended in $500 \mu \mathrm{L}$ of SDS $2 \%$ and incubated at room temperature for $30 \mathrm{~min}$; the samples were then centrifuged $(13,000 \mathrm{rpm}$ for $10 \mathrm{~min}$ ) and the supernatants were analyzed as above measuring the absorbance of PS 4 and PS $\mathbf{3}$ that, in SDS solution, are at $420 \mathrm{~nm}$ and $418 \mathrm{~nm}$, respectively. When necessary, the cell pellets were further treated with $\mathrm{HCl} 0.1 \mathrm{M}$. The porphyrin concentrations were obtained interpolating the data on a calibration plot in the range $1-10 \mu \mathrm{M}$. The experiments were performed in triplicate.

\subsection{Electron microscopy}

Aliquots of pure culture of $E$. coli and $E$. faecalis from photoinactivation experiments, were processed for electron microscopy observations, according to Tettamanti [25]. Briefly, after fixation in $4 \%$ glutaraldehyde for $1 \mathrm{~h}$ at room temperature, cells were postfixed in 1\% osmic acid for 20 min at room temperature. After dehydration in an ethanol series, they were embedded in an Epon/ Araldite 812 mixture. Thin sections, stained with uranyl acetate and lead citrate, were observed with a Jeol 1010 EX electron microscope. Images were acquired with an Olympus Morada TEM CCD camera.

\subsection{Statistical methods}

The photoinactivation experiments were repeated at least 3 times on separate dates. Mean and standard deviation calculations were performed using Microsoft Excel 2003 (Microsoft Corporation, Redmond, WA). Data were analyzed by means of one-way ANOVA (Origin ${ }^{\circledR} 7.0$ SR0). Significant effects of treatments $(p<0.05)$ were estimated with the following contrasts: -PS +light vs -PS -light; +PS -light vs $-\mathrm{PS}-\mathrm{L} ;+\mathrm{PS}+$ light vs $-\mathrm{PS}-$ light.

\section{Results}

\subsection{Synthesis and physical properties of diarylporphyrins}

The synthetic pathway proposed by Boyle [26] was chosen to synthesise the parent compound 5,15-di(4-pyridyl)porphyrin (2), from which the two cationic PSs, 5,15-di(N-methyl-4-pyridyl)porphyrin (3) and 5,15-di(N-benzyl-4-pyridyl)porphyrin (4), were obtained following $\mathrm{N}$-alkylation. Accordingly, 4-pyridylcarbaldehyde was reacted with a large excess of pyrrole affording the 5-(4-pyridyl)-dipyrromethane (1) in a good isolated yield (60\%) [15]. Compound 1 was then reacted with triethylorthoformate in $\mathrm{CH}_{2} \mathrm{Cl}_{2}$ in the presence of trifluoroacetic acid followed by air oxidation of porphyrinogen to porphyrin [16]. The chromatographic purification of the raw material yielded only $2 \%$ of the 5,15-di(4-pyridyl)porphyrin (2) (Scheme 1). The 5,15-di(N-methyl-4pyridyl)porphyrin (3) and the 5,15-di(N-benzyl-4-pyridyl)porphyrin (4), both featuring positively charged pyridinium groups on the molecular frame, were respectively obtained via alkylation of the pyridyl nitrogens refluxing the porphyrin $\mathbf{2}$ with methyliodide or benzylchloride used as solvents. The desired compounds $\mathbf{3}$ and $\mathbf{4}$ were isolated after the formation of a precipitate caused by the addition of diethylether (Scheme 1).

The octanol-water partition coefficient $(\log P)$ values for the benzyl derivative $\mathbf{4}$ and the methyl derivative $\mathbf{3}$ were of 0.92 and 0.18 , respectively. These data clear indicate a higher lipophilic character of the compound $\mathbf{4}$ with respect to $\mathbf{3}$.

The photobleaching of compounds $\mathbf{3}$ and $\mathbf{4}$ was measured following the decrease of their Soret absorption band following exposure to the white light of the $500 \mathrm{~W}$ halogen-tungsten lamp. No significant differences were observed comparing the two PSs, as both porphyrins maintained approximately $85 \%$ of the intensity of the initial Soret band after $2 \mathrm{~h}$ of light exposure (Fig. 1). These data ensure that no severe photoinduced degradation of the porphyrin frame occurs in the time course of bacteria photoinactivation assays. 


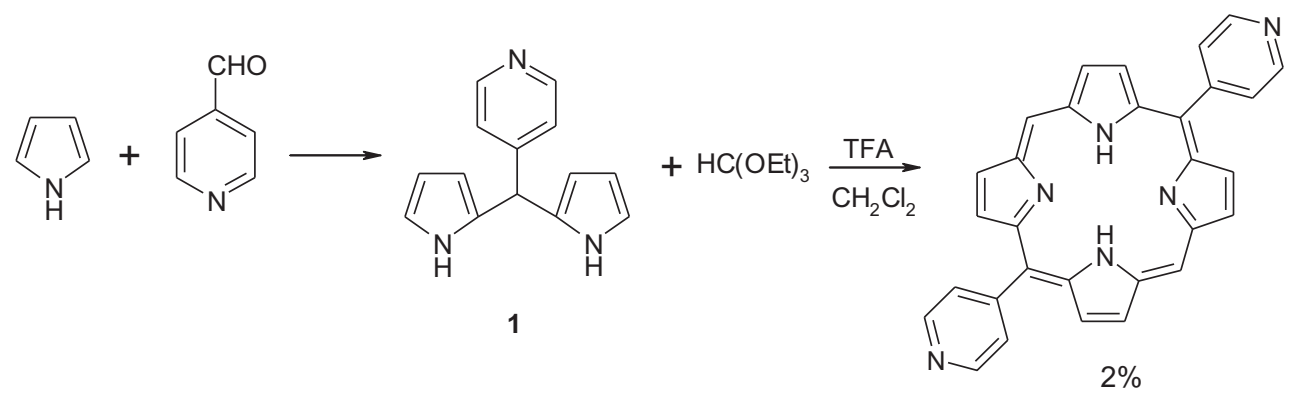

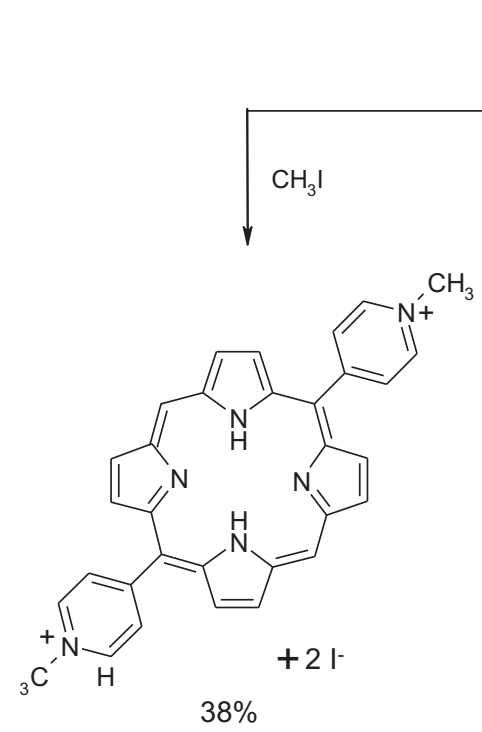

3

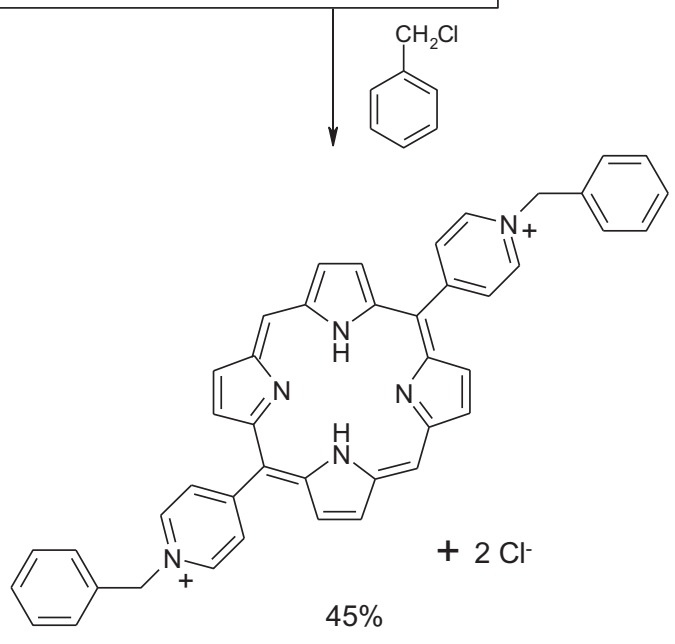

4

Scheme 1. Synthesis of the two cationic diarylporhpyrins 3 and 4.

As singlet oxygen is known to be the most important agent that mediates photocytotoxicity, the two diarylporphyrins were tested for the production of this reactive oxygen species following irradiation with a green LED device. With respect to Rose Bengal, the dye used as reference compound, PS $\mathbf{3}$ and PS $\mathbf{4}$ showed a quite low production of singlet oxygen, $2 \times 10^{-3}$ and $1 \times 10^{-3}$, respectively.

\subsection{Photoinactivation experiments}

The diarylporphyrins $\mathbf{3}$ and $\mathbf{4}$ were used to photoinactivate pure cultures of the model microorganisms E. coli C1a, a Gram negative bacterium, and E. faecalis ATCC51298, a Gram positive one. The photoinactivation experiments were performed using a bacterial density of $10^{7} \mathrm{CFU} / \mathrm{mL}$ and the irradiation was carried out in a static model at room temperature under artificial white light $(216 \mathrm{~J} /$ $\mathrm{cm}^{2}$ ); the viability of $E$. coli and $E$. faecalis was monitored using the plate count method as described above. E. faecalis was sensitive to photoinactivation induced by both PSs; the concentrations causing a viability decrease up to the detection limit were $5 \mu \mathrm{M}$ and $10 \mu \mathrm{M}$ for PS 4 and PS 3, respectively (Fig. 2). E. coli was completely insensitive to the treatment with PS 3, whereas the benzylated PS 4 caused a decrease of viable cells up to the detection limit at a concentration of $5 \mu \mathrm{M}$ (Fig. 2). Both E. coli and E. faecalis were not affected by irradiation in the absence of the PS (light control) or by the contact with any of the PSs tested in the absence of light (dark control) (Fig. S1 in Supplementary data).

The photokilling efficacy of the two PSs against $S$. aureus, a Gram-positive pathogen, and against $P$. aeruginosa, a Gram-negative opportunistic pathogen known to be more resistant to the

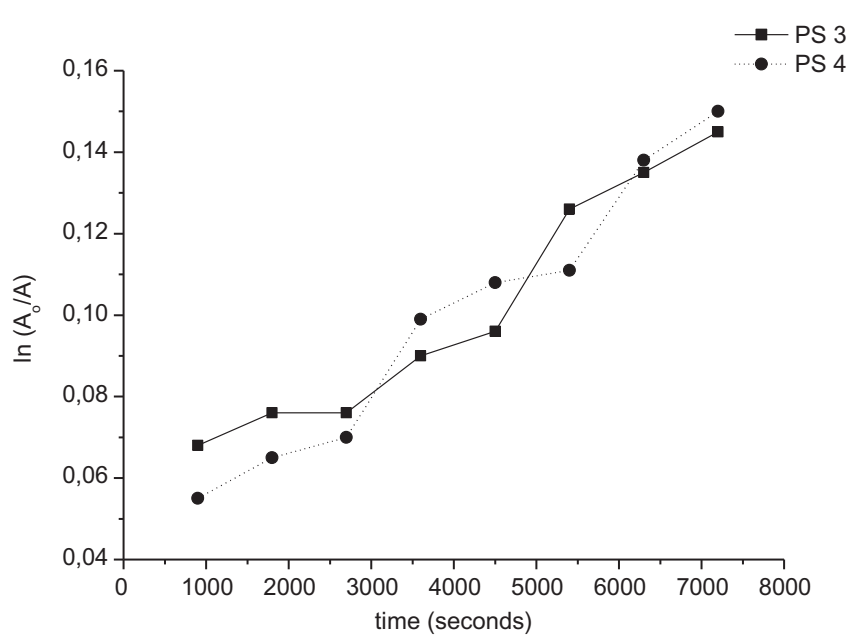

Fig. 1. Photobleaching of PS 3 (solid line) and PS 4 (dotted line) during $2 \mathrm{~h}$ irradiation with a $500 \mathrm{~W}$ halogen-tungsten lamp.

photodynamic treatment than the other organisms used in this study [27,28], was also evaluated. As observed in the case of $E$. coli, PS 3 was totally inactive against $P$. aeruginosa, whereas $10 \mu \mathrm{M}$ PS 4 caused a $4 \log$ unit decrease of viable cells. $1 \mu \mathrm{M}$ PS 4 caused the decrease of $S$. aureus viable cells to the detection limit, whereas a $5 \log$ unit decrease was observed by $5 \mu \mathrm{M}$ PS 3 (Fig. 3). Contrarily to what observed in E. faecalis cultures, increasing the PS 3 concentration did not improve the killing efficiency. 
PS 3

A
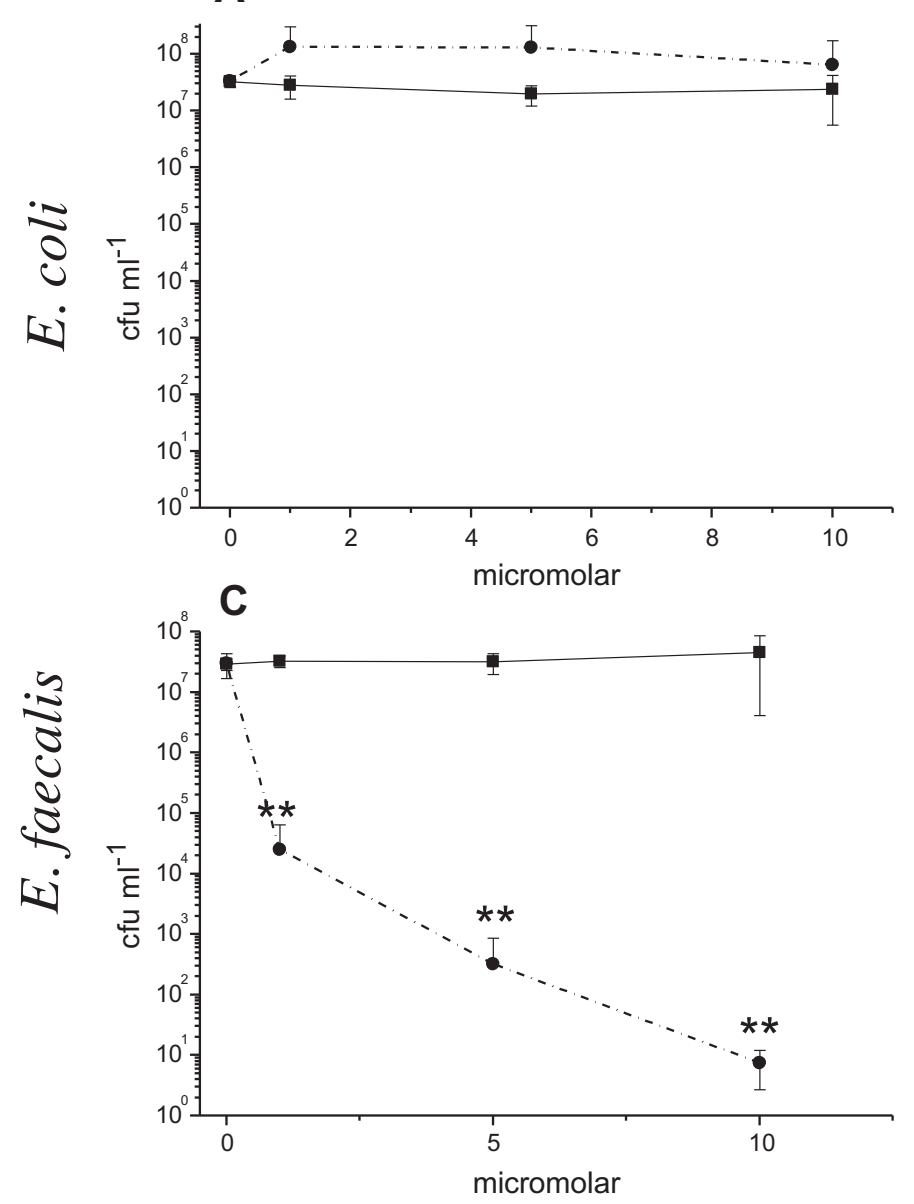

PS 4

B
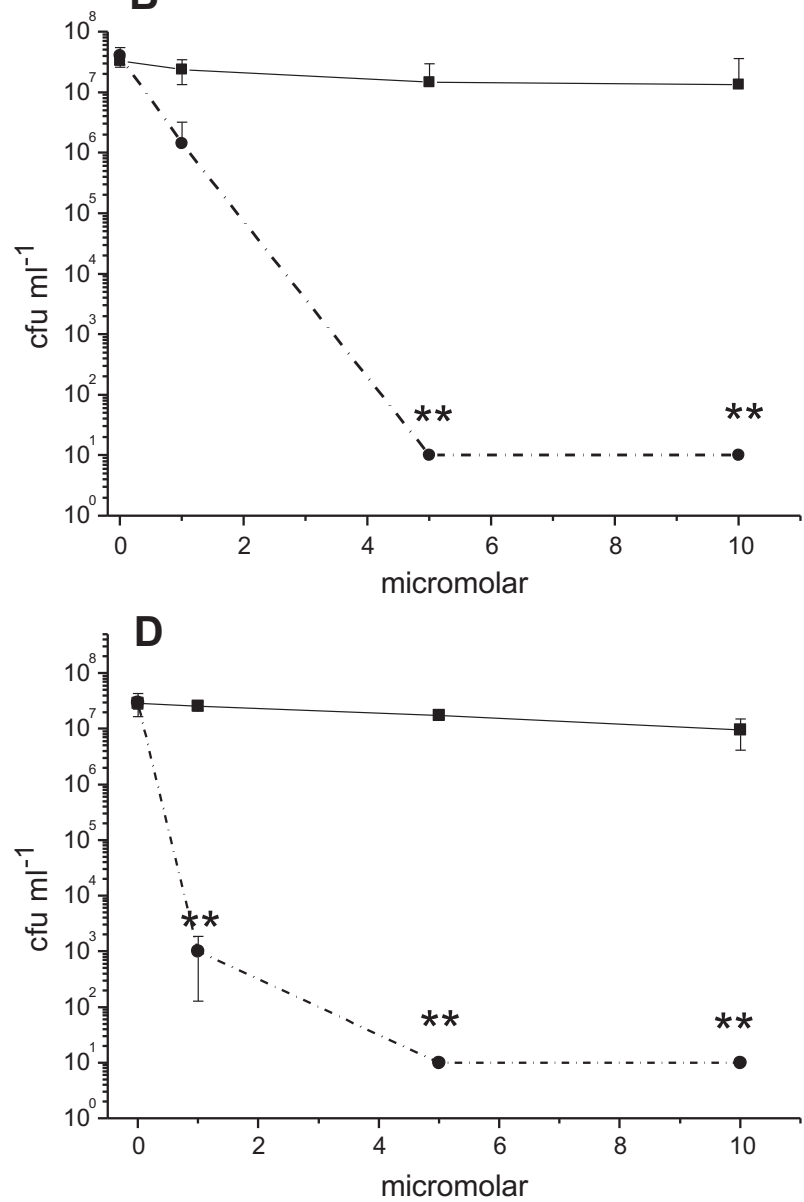

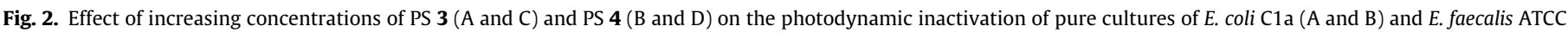

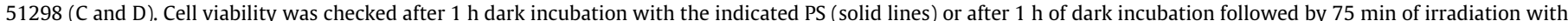

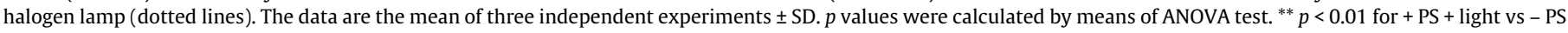
- light samples.

\subsection{Photosensitizer binding experiments}

In order to evaluate whether the different efficacy of the two PSs could be at least partially ascribable to a different binding to the model microorganisms E. coli and E. faecalis, up-take studies were performed. The methylated PS $\mathbf{3}$ was less prone to interact with bacterial cells than the benzylated one (4) (Fig. 4). In the E. coli suspensions exposed for $60 \mathrm{~min}$ to $10 \mu \mathrm{M}$ PS $\mathbf{3}$, $23.33 \pm 7.57 \%$ of the PS was found associated to the cells whereas $57.23 \pm 9.01 \%$ was found in the supernatant. When PS 4 was used, the amount of PS associated to the cells was the $94.20 \pm 18.20 \%$, and no residual PS $\mathbf{4}$ was detected in the supernatant. In E. faecalis, the amount of PS 3 associated to cells was $55.33 \pm 10.10 \%$ whereas the unbound fraction was $35.30 \pm 6.67 \%$. In analogy to what observed with $E$. coli no PS $\mathbf{4}$ could be detected in the supernatant. Following SDS treatment, it was possible to recover from $E$. faecalis cells the $53.40 \pm 6.70 \%$ of PS 4 ; the remaining PS could be recovered only with a further extraction with $\mathrm{HCl} 0.1 \mathrm{M}(54.00 \pm 4.00 \%)$.

\subsection{Induction of morphological changes}

Due to its higher efficiency in binding and in inducing lethality on both model organisms, PS $\mathbf{4}$ was chosen to investigate the changes induced to bacterial cell morphology following irradiation. E. coli or E. faecalis cell suspensions treated in the dark for $60 \mathrm{~min}$ with PS $4(5 \mu \mathrm{M})$ were irradiated with an energy dose $(28.08 \mathrm{~J} /$ $\mathrm{cm}^{2}$ ) low enough to avoid cell lysis and then analyzed by transmission electron microscopy (TEM).

As it can be observed from the representative TEM micrographs, after dark incubation with PS 4 (Fig. 5B), the morphology of the outer envelope of $E$. coli cells was comparable to that of the untreated and not irradiated control (Fig. 5A). The exposure to the PS in the absence of irradiation did not affect the cell viability despite a higher electron density was observed in the cytoplasm. Similarly, the irradiation alone did not alter both viability and cell morphology (not shown). On the other hand, after irradiation in the presence of PS $4(5 \mu \mathrm{M})$, morphological changes were observed at both envelope and cytoplasmic level. The outer membrane of approx. $90 \%$ of the treated cells appears fuzzier and lacks the pronounced margin of the envelope of control cells. Also the cytoplasmic compartment underwent changes: in approx. $60-70 \%$ of the cells we observed honeycomb-like structures (Fig. 5C) and in fewer cells (approx. $10 \%$ ) distinguished filamentary structures located in the nucleoid region (Fig. 5D); cytoplasmic regions less electron dense than those of the control samples were evident in approx. 90\% of the cells (Fig. 5E). These peculiar ultrastructural changes were observed only in PS treated and irradiated cells, but not in control samples; this rules out the hypothesis of possible artifacts.

E. faecalis cells show more evident intracytoplasmic alteration with respect to E. coli ones, in accordance with the higher 
PS 3

A
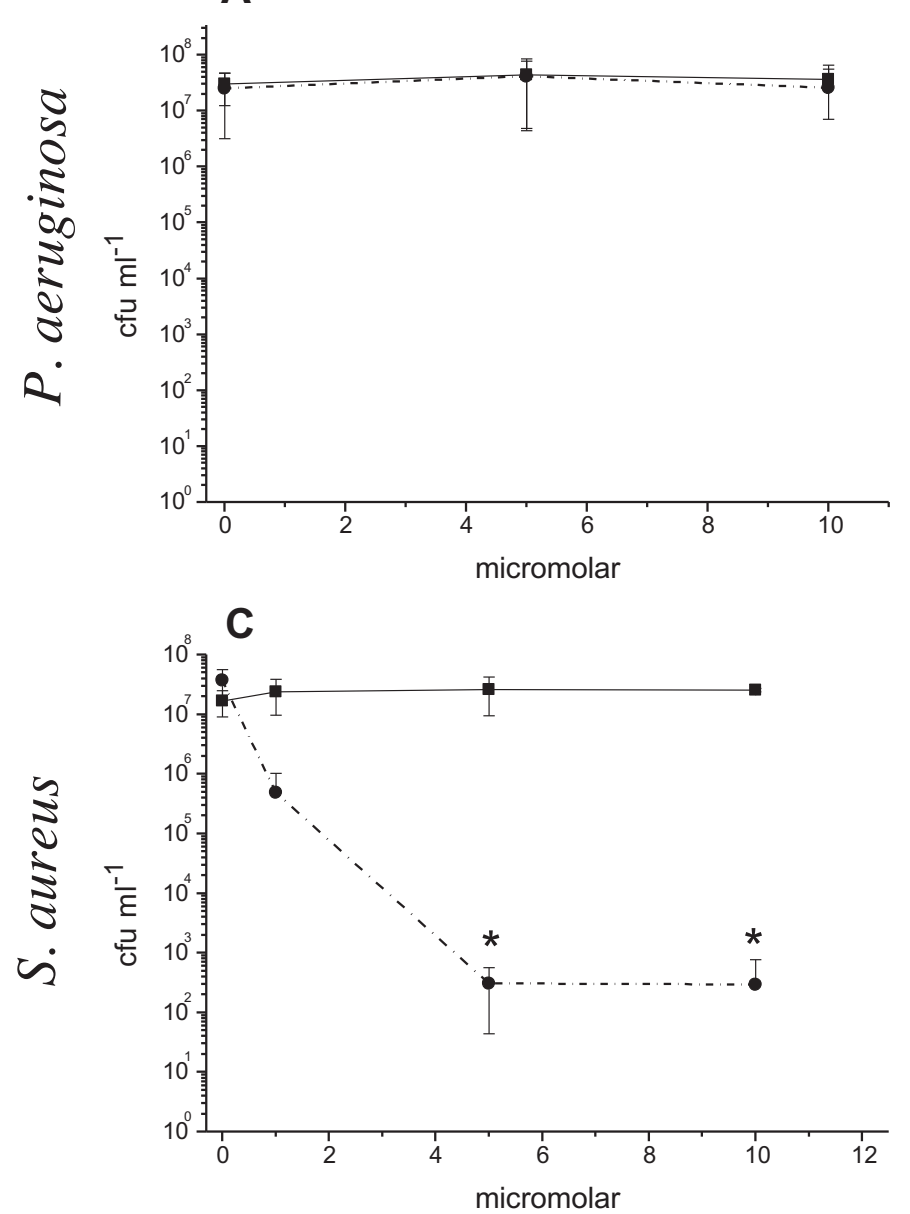

PS 4

B
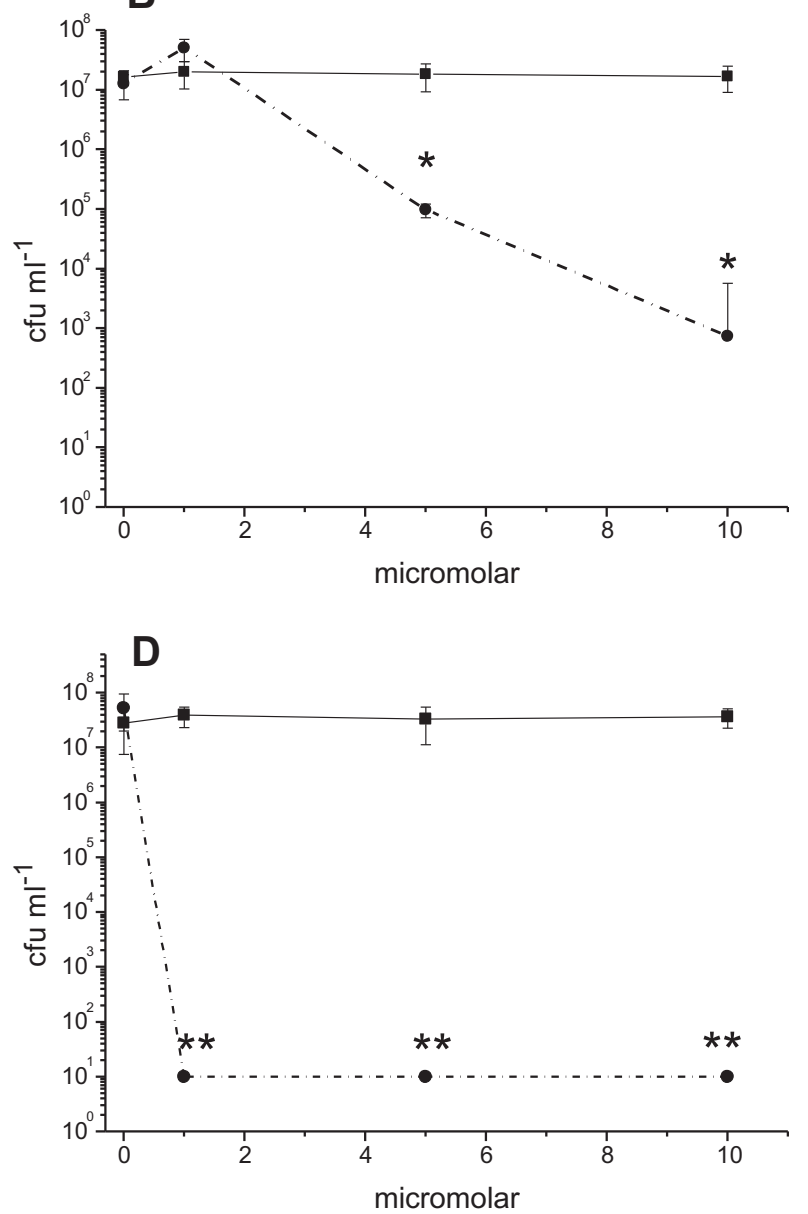

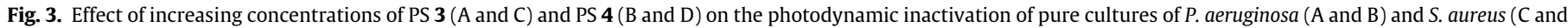

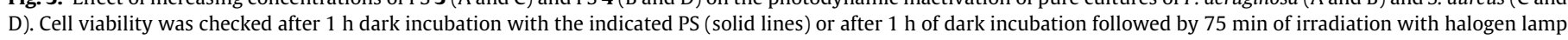

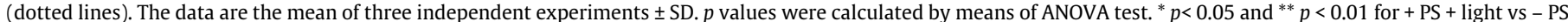
- light samples.
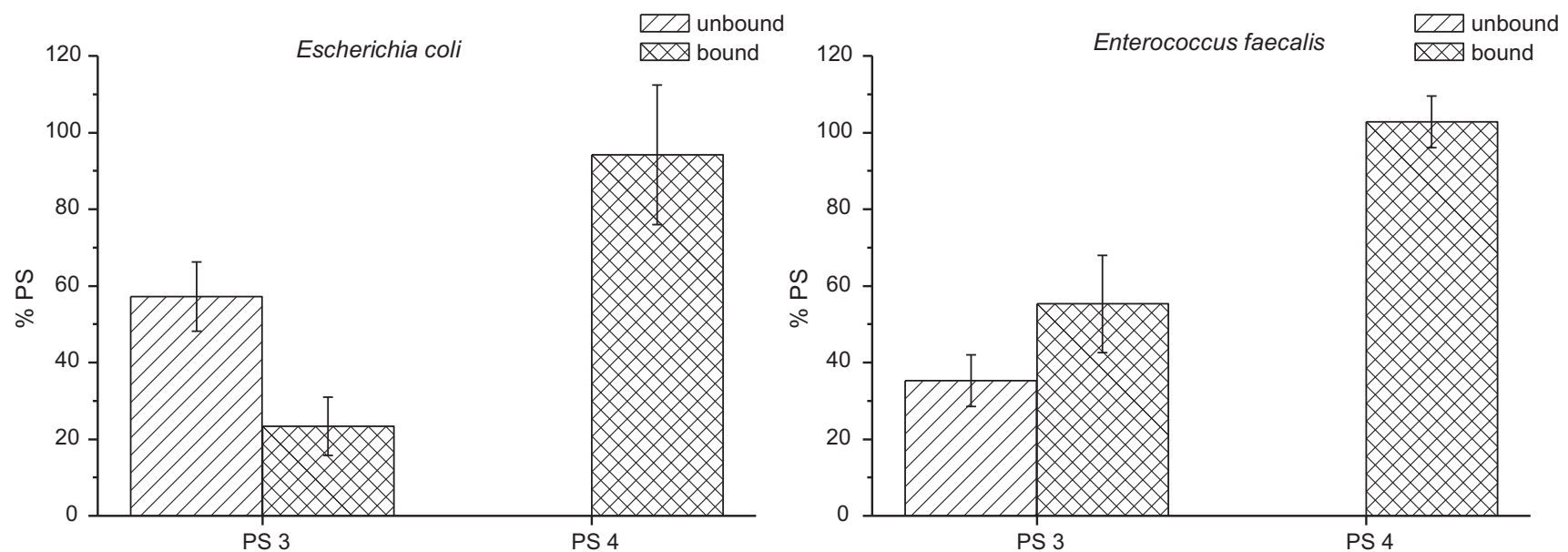

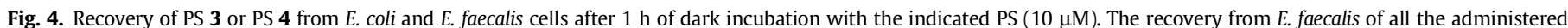

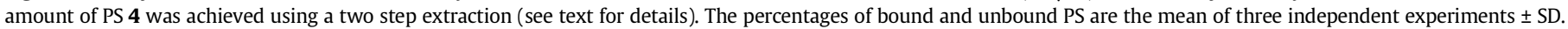

susceptibility of this microorganism to photoinactivation. Although $5 \mu \mathrm{M}$ PS 4 was not intrinsically toxic to E. faecalis cells (Fig. 6B), micrograph images were fuzzy and cells looked different from those of the untreated and not irradiated control (Fig. 6A), exhibiting ultrastructural alterations such as a less dense cell wall and presence of low-density areas in the cytoplasm. Upon irradiation, in quite almost the fields analyzed, PS treated E. faecalis cells showed a filamentary organization of the nucleoid region (Fig. 6C) 

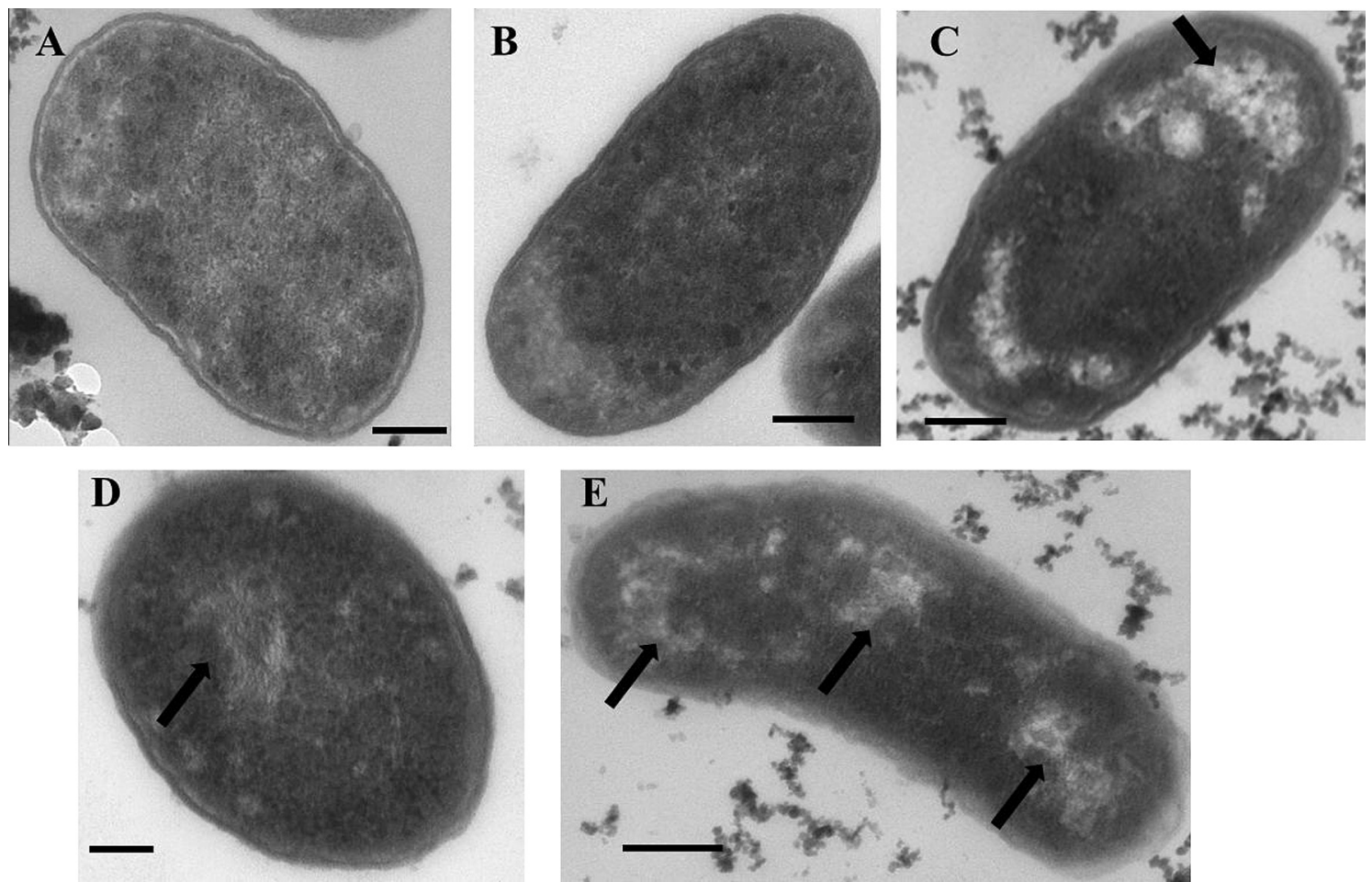

Fig. 5. Representative TEM micrographs of $E$. coli cells photosensitized for 10 min with $5 \mu \mathrm{M}$ PS 4. A, - PS - light; B, + PS - light; C, D, E, + PS + light (bar = 500 nm).
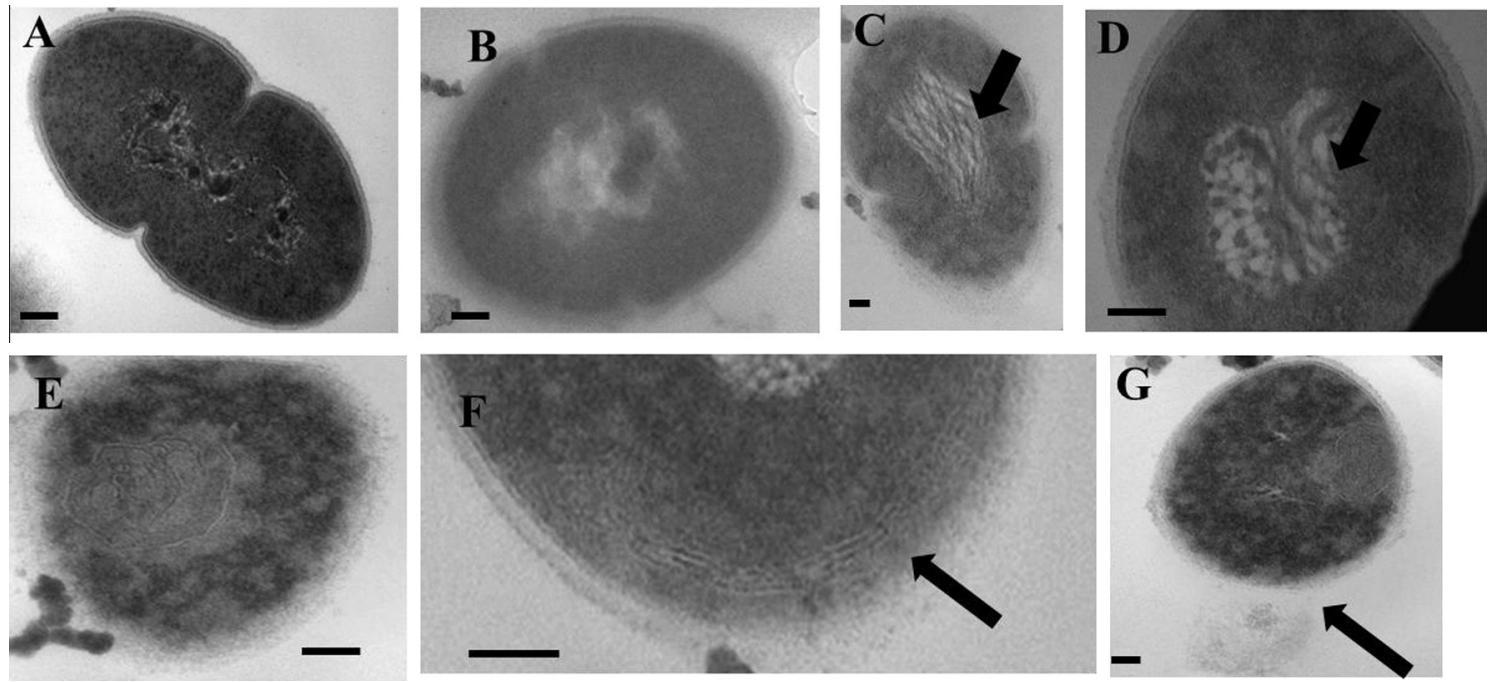

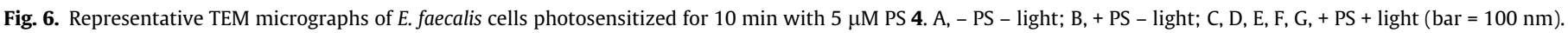

or, alternatively, a honeycomb-like structure (Fig. 6D and E) not present in the control samples (Fig. 6A). In photosensitized $E$. faecalis cells, a further peculiar structure was found consisting of folded structures parallel to the inner face of plasma membrane (Fig. 6F). The alterations of the cytoplasmic membrane could also be responsible for the formation of the bubbles or for the leakage of the inner content observed in only few E. faecalis cells (Fig. 6G), but not in E. coli.

\subsection{Potential of PS 4 in the disinfection of bacterial water contaminants}

For a deeper investigation on PS $\mathbf{4}$ potentialities, the efficiency of halogen and sun lights in photoinactivation experiments against mixed suspensions of E. coli and E. faecalis, bacteria regarded as indicators of faecal contamination, was compared (Fig. 7). Outdoor experiments were performed during the winter season (light intensity ranging from 28,000 to 53,000 lux and air temperature from $5{ }^{\circ} \mathrm{C}$ to $9{ }^{\circ} \mathrm{C}$ ), administering PS 4 at $5 \mu \mathrm{M}$, the concentration which determined in the indoor experiment the greatest cell decrease detectable in the system (6 log units). To rule out any UV$A$ and UV-B bactericidal action, UV filter screened controls were also set up. As reported in Fig. 7, the viability of both E. coli and E. faecalis in mixed suspensions was neither affected by irradiation itself nor by $5 \mu \mathrm{M}$ PS $\mathbf{4}$ in the absence of irradiation. In PS treated samples a $6 \log$ unit viability reduction was achieved for both microorganisms regardless the light source used.

Similar experiments were also carried out on the effluents of an activated sludge treatment plant, collected after the secondary 


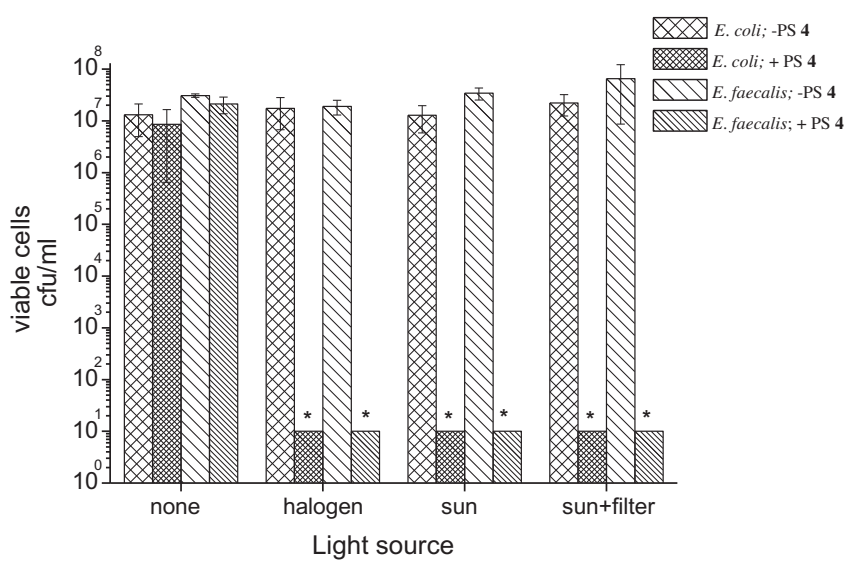

Fig. 7. Effect of photodynamic treatment with $5 \mu \mathrm{M}$ PS 4 on mixed cultures of $E$. coli C1a and E. faecalis ATCC 51298. The viability of the two microorganisms was checked by plate count on specific selective media after $1 \mathrm{~h}$ incubation in the dark or after dark incubation followed by 75 min irradiation with either halogen lamp, sunlight, or UV-screened sunlight. The data are the mean of three independent experiments \pm SD. $p$ values were calculated by means of ANOVA test. ${ }^{*} p<0.05$ for + PS + light samples versus - PS - light samples.

sedimentation, to check the effectiveness of photosensitization with PS 4 against wild microorganisms in a complex matrix. After 75 min of exposure, an average 2 log unit decrease of heterotrophic bacteria and of faecal coliforms was observed independently from the irradiation conditions. The treatment was more efficient against Enterococci as their population density decreased up to the detection limit (Table 1). Two fold increasing of the irradiation time (i.e. doubling the light dose) resulted, at best, in a further decrease of only $1 \log$ unit of the monitored microflora (Table S1 and Fig. S2 in Supplementary data).

\section{Discussion}

The efficacy of porphyrin photosensitizers in photodynamic antimicrobial treatment depends on several structural and chemico-physical parameters. The presence of positive charges on the PS is mandatory to achieve a good activity against Gram negative bacteria [29], as positive charges promote a tight electrostatic interaction with negatively charged sites at the outer surface of the bacterial cells. The PS stuck on the bacterial cell surface exerts an efficient photodynamic action because the short living singlet oxygen, generated by energy transfer from the PS in the excited state to the molecular oxygen, easily reacts with the organic molecules of the cell wall thus impairing its integrity $[13,30]$. On the other hand, PS-cell interaction can be enhanced using molecules endowed with a certain degree of lipophilicity, that facilitates their penetration through cell membranes [32]. Hussain observed that among the cationic phenothiazinium-based compounds (PhBPs), the somewhat lipophilic ones $(\log P>0.5)$ were more active with respect to the hydrophilic congeners against the Gram-negative E. coli [7]. Among the previously synthesized tetracationic porphyrins already reported [33] the one featuring four benzyl groups as alkylating agent of the pyridyl nitrogen $(5,10,15,20$-Tetra(N-benzyl-4-pyridyl)porphyrin tetrachloride, TBzPyP) was found the most active, although its $\log P$ was negative $(\log P=-1)$. In the same paper the activity of one dicationic congener serendipity isolated by partial alkylation of the tetrapyridyl porphyrin moiety was also described. This last compound was more efficient than the TBzPyP and its $\log P$, although still negative, was the highest of all the tested cationic compounds $(\log P=-0.52)$.

To study cationic PSs characterized by the presence of two positive charges only the structure of the 5,15-dipyridylporphyrin, from which the corresponding dicationic compounds can be easily and unequivocally achieved following $\mathrm{N}$-alkylation, was conceived. The general synthetic pathway proposed by Boyle [26] was chosen for the synthesis of compound $\mathbf{2}$ as it requires the preparation of only one dipyrrolylmethane intermediate that can undergo cyclization to porphyrin via condensation with a single carbon atom reagent, such as formaldehyde or orthoformate. Concerning the low isolated yield of the porphyrin 2, that one obtained (2\%) is not too low with respect to that one reported in the literature (8\%, [16]). Actually it is known that condensation yields of electron deficient aldehydes (such the 4-pyridinecarboxaldehyde) with pyrrole are by far lower than those obtained with electron rich aldehydes [16]. Indeed, in previously published syntheses of 5,15-diarylporphyrins, in which the aromatic moieties belonged to the nitrosubstituted benzaldehydes, the yields of the isolated porphyrins were about 5\% [34]. In analogy, it is not surprising that dipyrrolylmethane bearing the pyridine on "meso" position hardly reacts with orthoformate to afford the desired porphyrin. It must be pointed out that, in order to overcome this drawback, we also made a few attempts following a different synthetic approach (data not shown) in which the "meso" unsubstituted dipyrrolylmethane was made to react with the 4-pyridinecarboxaldehyde. Unfortunately, the yield of the isolated porphyrin 2 was comparable to that one of the above mentioned synthetic pathway.

The last step of the synthetic effort concerned the alkylation of the neutral porphyrin $\mathbf{2}$ with two different alkyl halides. This reaction has been successfully carried out in the presence of a large excess of alkyl halide used as solvent, thus the two dicationic

Table 1

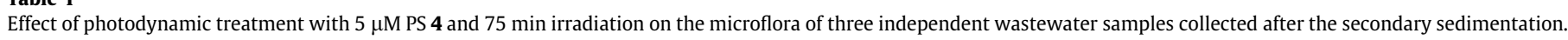

\begin{tabular}{|c|c|c|c|c|c|c|c|c|c|}
\hline & \multicolumn{3}{|l|}{-PS 4} & \multicolumn{6}{|l|}{ +PS 4} \\
\hline & $\begin{array}{l}\text { Heterotrophic } \\
\text { bacteria (PCA) } \\
(\mathrm{CFU} / \mathrm{mL})\end{array}$ & $\begin{array}{l}\text { Faecal coliform } \\
\text { (mFC agar) } \\
(\mathrm{CFU} / \mathrm{mL})\end{array}$ & $\begin{array}{l}\text { Faecal } \\
\text { enterococci (KF } \\
\text { agar) }(\mathrm{CFU} / \mathrm{mL})\end{array}$ & $\begin{array}{l}\text { Heterotrophic } \\
\text { bacteria (PCA) } \\
(\mathrm{CFU} / \mathrm{mL})\end{array}$ & $\begin{array}{l}\text { Log unit } \\
\text { reduction }\end{array}$ & $\begin{array}{l}\text { Faecal coliform } \\
\text { (mFC agar) } \\
(\mathrm{CFU} / \mathrm{mL})\end{array}$ & $\begin{array}{l}\text { Log unit } \\
\text { reduction }\end{array}$ & $\begin{array}{l}\text { Faecal } \\
\text { enterococci (KF } \\
\text { agar) }(\mathrm{CFU} / \mathrm{mL})\end{array}$ & $\begin{array}{l}\text { Log unit } \\
\text { reduction }\end{array}$ \\
\hline $60^{\prime}$ dark & $\begin{array}{l}1.8 \times 10^{5} \\
4.9 \times 10^{5} \\
4.6 \times 10^{5}\end{array}$ & $\begin{array}{l}6.7 \times 10^{4} \\
7.0 \times 10^{4} \\
5.5 \times 10^{4}\end{array}$ & $\begin{array}{l}8.0 \times 10^{3} \\
1.9 \times 10^{4} \\
1.5 \times 10^{4}\end{array}$ & $\begin{array}{l}1.0 \times 10^{5} \\
3.3 \times 10^{5} \\
4.4 \times 10^{5}\end{array}$ & $\begin{array}{l}0 \\
0 \\
0\end{array}$ & $\begin{array}{l}4.4 \times 10^{4} \\
4.0 \times 10^{4} \\
8.0 \times 10^{4}\end{array}$ & $\begin{array}{l}0 \\
0 \\
0\end{array}$ & $\begin{array}{l}2.6 \times 10^{3} \\
2.6 \times 10^{3} \\
3.3 \times 10^{3}\end{array}$ & $\begin{array}{l}0 \\
1 \\
1\end{array}$ \\
\hline $75^{\prime}$ sun & $\begin{array}{l}8.3 \times 10^{5} \\
1.5 \times 10^{5} \\
1.5 \times 10^{5}\end{array}$ & $\begin{array}{l}1.5 \times 10^{4} \\
5.0 \times 10^{3} \\
2.5 \times 10^{4}\end{array}$ & $\begin{array}{l}1.3 \times 10^{3} \\
3.2 \times 10^{3} \\
4.1 \times 10^{3}\end{array}$ & $\begin{array}{l}1.8 \times 10^{4} \\
6.0 \times 10^{3} \\
1.5 \times 10^{3}\end{array}$ & $\begin{array}{l}1 \\
2 \\
2\end{array}$ & $\begin{array}{l}30 \\
8.0 \times 10^{2} \\
1.8 \times 10^{2}\end{array}$ & $\begin{array}{l}3 \\
1 \\
2\end{array}$ & $\begin{array}{l}<10 \\
<10 \\
<10\end{array}$ & $\begin{array}{l}3 \\
3 \\
3\end{array}$ \\
\hline $75^{\prime}$ sun + filter & $\begin{array}{l}1.2 \times 10^{5} \\
1.7 \times 10^{5} \\
1.7 \times 10^{5}\end{array}$ & $\begin{array}{l}4.6 \times 10^{4} \\
1.4 \times 10^{4} \\
1.5 \times 10^{5}\end{array}$ & $\begin{array}{l}3.2 \times 10^{3} \\
4.6 \times 10^{3} \\
2.0 \times 10^{3}\end{array}$ & $\begin{array}{l}1.5 \times 10^{4} \\
2.5 \times 10^{3} \\
5.0 \times 10^{3}\end{array}$ & $\begin{array}{l}1 \\
2 \\
2\end{array}$ & $\begin{array}{l}50 \\
7.0 \times 10^{2} \\
4.5 \times 10^{2}\end{array}$ & $\begin{array}{l}3 \\
2 \\
3\end{array}$ & $\begin{array}{l}<10 \\
20 \\
<10\end{array}$ & $\begin{array}{l}3 \\
3 \\
3\end{array}$ \\
\hline $75^{\prime}$ halogen lamp & $\begin{array}{l}6.7 \times 10^{4} \\
2.2 \times 10^{5} \\
3.0 \times 10^{5}\end{array}$ & $\begin{array}{l}2.8 \times 10^{4} \\
3.0 \times 10^{4} \\
1.1 \times 10^{5}\end{array}$ & $\begin{array}{l}4.5 \times 10^{3} \\
2.8 \times 10^{3} \\
5.0 \times 10^{3}\end{array}$ & $\begin{array}{l}4.0 \times 10^{4} \\
1.7 \times 10^{3} \\
6.0 \times 10^{3}\end{array}$ & $\begin{array}{l}0 \\
2 \\
2\end{array}$ & $\begin{array}{l}4.0 \times 10^{2} \\
4.0 \times 10^{2} \\
3.2 \times 10^{3}\end{array}$ & $\begin{array}{l}2 \\
2 \\
2\end{array}$ & $\begin{array}{l}<10 \\
<10 \\
<10\end{array}$ & $\begin{array}{l}3 \\
3 \\
3\end{array}$ \\
\hline
\end{tabular}


porphyrins, the methylated derivative PS 3 and the benzylated one PS $\mathbf{4}$ could be isolated by filtration following precipitation.

The chemico-physical studies of the two porphyrins indicate that the two compounds are characterized by similar photostability and singlet oxygen production rate but different lipophilicity. Both compounds showed a positive $\log P$ values and, in particular, compound 4 showed a $\log P>0.5$, the value indicated by Hussain et al. [7] necessary to obtain a good interaction with Gram negative bacteria.

PS 3 and PS 4 were first tested against pure cultures of Gram negative, E. coli and P. aeruginosa, and Gram positive, E. faecalis and $S$. aureus, bacteria. Independently from the PS used, the Gram negative bacteria were, as expected, less sensitive to the photodynamic treatment than the Gram positive ones. The lower sensitivity of Gram-negative bacteria is well documented and it has been ascribed to the structure of the cell wall and, in particular, to the presence of the outer membrane which makes these microorganisms less prone to PS penetration [5,6]. The presence of benzylic groups makes PS $\mathbf{4}$ more lipophilic than PS $\mathbf{3}$ thus more suitable to interact with the Gram negative lipopolysaccharidic outer membrane, and, ultimately, active also against these bacteria. It is also noticeable the absence of toxicity in the dark of both these new compounds up to $10 \mu \mathrm{M}$, whereas the TBzPyP previously reported showed a clear dark toxicity (unpublished data). At the same time the comparison of the photodynamic efficacy of the dicationic porphyrin 4 is higher with respect to that one of the TBzPyP determined under comparable experimental conditions.

Accordingly to what expected on the basis of PS lipophilicity, in E. coli, binding experiments showed that almost the whole amount of PS $\mathbf{4}$ administered was recovered after cellular lysis, whereas the PS 3 was remarkably less bound to the cells. Also in E. faecalis the entire amount of PS 4 was found bound to the cells, but only $50 \%$ could be recovered following a SDS treatment, the remaining fraction could be recovered only after the $\mathrm{HCl} 0.1 \mathrm{M}$ treatment, suggesting that the PS is strongly bound to the cells. The PS 3, more polar than PS 4, showed a lower binding degree to the Gram-positive cells as $35 \%$ was recovered in the supernatant.

The comparable singlet oxygen production by the two PSs is not surprising as the peripheral substituents present on these porphyrins can hardly influence the electronic excitation and relaxation pathways of the tetrapyrrolic ring. As the consequence, the higher efficiency in photokilling of PS $\mathbf{4}$ with respect to PS $\mathbf{3}$ seems to be mainly ascribable to a better interaction with the bacterial cells.

At the early stages of the photoinactivation process, the cells treated with PS $\mathbf{4}$ underwent significant morphological alterations leading to cell death. The intracellular alterations detected were greater and more diffuse in the Gram positive E. faecalis cells than in $E$. coli cells, in agreement with the observations of Nitzan on the Gram positive model bacterium $S$. aureus and the Gram negative E. coli following photoinactivation with $\delta$-ALA [34]. In E. faecalis, as in S. aureus [35], honeycomb like structure were observed. In $E$. coli the cell envelop appeared to be compromised and the cytoplasm appearance was quite different from that of healthy cells. Pudziuvyte et al. [36] observed similar alterations after irradiation of E. coli KMY1 treated with tetra-(4-ethylpyridynium)porphyrin tetratosylate; the authors assumed that this damage could increase the outer membrane permeability, thus favoring porphyrin cell penetration that in turn results in more photo-oxidative damages.

The mechanism of prokaryotic cell killing exerted by the photodynamic treatment makes this procedures a powerful mean to reduce bacterial cell number, which can be potentially applied to different matrices [37-38]. To these purposes the use of an economic and broad spectrum light source is advisable. We thus investigated whether the combination of sunlight with PS 4, could be efficiently used in the photoinactivation of mixed cultures of the model organisms E. coli and E. faecalis.
In the outdoor experiments the sunlight of bright winter days was found as efficient as the halogen lamp in the photoinactivation of a mixture of the faecal indicators E. coli and E. faecalis; furthermore the UV contribution to this process appeared to be negligible as comparable results were obtained shielding the culture with an UV filter. When the same protocol was applied to wastewater samples, a good killing yield was obtained for all the monitored components of the microflora, although lower than that achieved with the mixed cultures of the model microorganisms $E$. coli and E. faecalis. Such lower efficiency is probably ascribable to the presence of particulate matter which can trap some of the PS, making it less available to the cells. The presence of organic matter has been demonstrated to negatively affect the binding of a tetracationic porphyrin to $P$. aeruginosa and thus its efficacy after irradiation [40]. The quite low reduction of the heterotrophic subpopulation can account for the presence of a high proportion of Gram negative bacteria such as strains related to Pseudomonads, that, in general, undergo photoeradication with great difficulty. On the contrary, the subpopulation of wild Enterococci showed a higher sensitivity than heterotrophic and faecal coliforms bacteria, to PS itself and to irradiation, as also reported by other authors $[41,41]$. PS $\mathbf{4}$ can thus be considered potentially useful in the disinfection of bacteria contaminated waters, and its potentiality is strengthened by the possibility to use solar light for the photoactivation. However, the feasibility of such application needs the study of new synthetic procedures aimed to increase the yield to reasonable values and a broader investigation of its antimicrobial activity.

The present study confirms that the new dicationic, 5,15-dipyridylporphyrins represent a class of photosensitizing agents endowed with an efficient antibacterial activity on different bacterial species under different irradiating conditions and at concentrations as low as the tetracationic congeners previously reported [33]. On the whole the results pointed out that a limited number of positive charges together with a certain degree of lipophilicity enhance the interaction of the PS $\mathbf{4}$ with the bacterial cells. This better interaction can be responsible for the higher efficacy of this PS against both Gram positive and Gram negative bacteria.

\section{Abbreviations}

\begin{tabular}{ll} 
PDT & photodynamic therapy \\
PS & photosensitizer \\
O/N & over/night \\
LB & Luria Bertani Broth \\
\hline
\end{tabular}

\section{Acknowledgements}

This research was funded by the University of Insubria (Fondo di Ateneo per la Ricerca). We thank Giada Luraschi, Cristina Vianello and Dr. Luca Bianchi for collaboration in the experimental work.

\section{Appendix A. Supplementary material}

Supplementary data associated with this article can be found, in the online version, at http://dx.doi.org/10.1016/j.jphotobiol.2013. 08.011.

\section{References}

[1] I.J. MacDonald, T.J. Dougherty, Basic principles of photodynamic therapy, Journal of Porphyrins and Phthalocyanines 5 (2001) 105-129.

[2] M. Wainwright, Photodynamic antimicrobial chemotherapy (PACT), Journal of Antimicrobial Chemotherapy 42 (1998) 13-28. 
[3] P.D. Rao, S. Dhanalekshmi, B.J. Littler, J.S. Lindsey, Rational syntheses of porphyrins bearing up to four different meso substituents, Journal of Organic Chemistry 65 (2000) 7323-7344.

[4] L. Huang, T. Dai, M.R. Hamblin, Antimicrobial photodynamic inactivation and photodynamic therapy for infections, Methods in Molecular Biology 635 (2010) 155-173.

[5] Z. Malik, H. Ladan, Y. Nitzan, Photodynamic inactivation of Gram-negative bacteria - problems and possible solutions, Journal of Photochemistry and Photobiology B - Biology 14 (1992) 262-266.

[6] A. Minnock, D.I. Vernon, J. Schofield, J. Griffiths, J.H. Parish, S.B. Brown, Photoinactivation of bacteria. Use of a cationic water-soluble zinc phthalocyanine to photoinactivate both Gram-negative and Gram-positive bacteria, Journal of Photochemistry and Photobiology B - Biology 32 (1996) $159-164$.

[7] S. Hussain, F. Harris, D.A. Phoenix, The phototoxicity of phenothiaziniumbased photosensitizers to bacterial membranes, FEMS Immunology and Medical Microbiology 46 (2006) 124-130.

[8] G. Jori, M. Magaraggia, C. Fabris, M. Soncin, M. Camerin, L. Tallandini, O. Coppellotti, L. Guidolin, Photodynamic inactivation of microbial pathogens: disinfection of water and prevention of water-borne diseases, Journal of Environmental Pathology, Toxicology and Oncology 30 (2011) 261-271.

[9] C.M.B. Carvalho, A.T.P.C. Gomes, S.C.D. Fernandes, A.C.B. Prata, M.A. Almeida, M.A. Cunha, J.P.C. Tome, M.A.F. Faustino, M.G.P.M. Neves, A.C. Tome, J.A.S. Cavaleiro, Z. Lin, J.P. Rainho, J. Rocha, Photoinactivation of bacteria in wastewater by porphyrins: bacterial beta-galactosidase activity and leucineuptake as methods to monitor the process, Journal of Photochemistry and Photobiology B - Biology 88 (2007) 112-118.

[10] M. Salmon-Divon, Y. Nitzan, Z. Malik, Mechanistic aspects of Escherichia coli photodynamic inactivation by cationic tetra-meso(N-methylpyridyl)porphine, Photochemical \& Photobiological Sciences 3 (2004) 423-429.

[11] E. Reddi, M. Ceccon, G. Valduga, G. Jori, J.C. Bommer, F. Elisei, L. Latterini, U. Mazzucato, Photophysical properties and antibacterial activity of mesosubstituted cationic porphyrins, Photochemistry and Photobiology 75 (2002) 462-470.

[12] M.B. Spesia, D. Lazzeri, L. Pascual, M. Rovera, E.N. Durantini, Photoinactivation of Escherichia coli using porphyrin derivatives with different number of cationic charges, FEMS Immunology and Medical Microbiology 44 (2005) 289295.

[13] D.A. Caminos, M.B. Spesia, P. Pons, E.N. Durantini, Mechanisms of Escherichia coli photodynamic inactivation by an amphiphilic tricationic porphyrin and 5,10,15,20-tetra(4-N,N,N-trimethylammoniumphenyl) Photochemical \& Photobiological Sciences 7 (2008) 1071-1078.

[14] M.B. Gariboldi, R. Ravizza, P. Baranyai, E. Caruso, S. Banfi, S. Meschini, E. Monti, Photodynamic effects of novel 5,15-diaryl-tetrapyrrole derivatives on human colon carcinoma cells, Bioorganic \& Medicinal Chemistry 17 (2009) 20092016.

[15] D. Gryko, J.S. Lindsey, Rational synthesis of meso-substituted porphyrins bearing one nitrogen heterocyclic group, Journal of Organic Chemistry 65 (2000) 2249-2252.

[16] D.P.N. Goncalves, S. Ladame, S. Balasubramanian, J.K.M. Sanders, Synthesis and G-quadruplex binding studies of new 4-N-methylpyridinium porphyrins, Organic \& Biomolecular Chemistry 4 (2006) 3337-3342.

[17] I. Scalise, E.N. Durantini, Photodynamic effect of metallo 5-(4-carboxyphenyl)10,15,20-tris(4-methylphenyl) porphyrins in biomimetic AOT reverse micelles containing urease, Journal of Photochemistry and Photobiology A - Chemistry 162 (2004) 105-113.

[18] I.E. Kochevar, R.W. Redmond, Photosensitized production of singlet oxygen, Singlet Oxygen, Uv-A, and Ozone 319 (2000) 20-28.

[19] C.I. Sasaki, G. Bertani, Growth abnormalities in Hfr derivatives of Escherichia coli strain C, Journal General Microbiology 40 (1965) 365-376.

[20] L.M. Kopit, L.J. Harris, M.L. Marco, Draft genome sequence of the quality control strain Enterococcus faecalis ATCC 29212, Journal Bacteriology 21 (2012) 6006-6007.

[21] C.K. Stover, X.Q. Pham, A.L. Erwin, S.D. Mizoguchi, P. Warrener, M.J. Hickey, Complete genome sequence of Pseudomonas aeruginosa PA01, an opportunistic pathogen, Nature 406 (2000) 959-964.
22] T. Ito, Y. Katayama, K. Asada, N. Mori, K. Tsutsumimoto, C. Tiensasitorn, K. Hiramatsu, Structural comparison of three types of staphylococcal cassette chromosome mec integrated in the chromosome in methicillin-resistant Staphylococcus aureus, Antimicrobial Agents and Chemotherapy 5 (2001) 1323-1336.

[23] J.H. Miller, Experiments in Molecular Genetics, Cold Spring Harbour Ed., New York, 1972.

[24] M. Khan, R. Kolter, C. Thomas, D. Figurski, R. Meyer, E. Remaut, D.R. Helinski, Plasmid cloning vehicles derived from plasmids ColE 1, F, R6K and RK2, Methods in Enzymology 68 (1979) 268-280.

[25] G. Tettamanti, D. Malagoli, In vitro methods to monitor autophagy in Lepidoptera, Autophagy: Lower Eukaryotes and Non-Mammalian Systems, Pt A 451 (2008) 685-709.

[26] R.W. Boyle, C. Bruckner, J. Posakony, B.R. James, D. Dolphin, 5Phenyldipyrromethane and 5,15-diphenylporphyrin, Organic Syntheses 761999 (76) (1999) 287-293.

[27] T.O. Philippova, B.N. Galkin, O.Y. Zinchenko, M.Y. Rusakova, V.A. Ivanitsa, Z.I. Zhilina, S.V. Vodzinskii, Y.V. Ishkov, The antimicrobial properties of new synthetic porphyrins, Journal of Porphyrins and Phthalocyanines 7 (2003) $755-760$.

[28] G.P. Tegos, M. Anbe, C.M. Yang, T.N. Demidova, M. Satti, P. Mroz, S. Janjua, F. Gad, M.R. Hamblin, Protease-stable polycationic photosensitizer conjugates between polyethyleneimine and chlorin(e6) for broad-spectrum antimicrobial photoinactivation, Antimicrobial Agents and Chemotherapy 50 (2006) 1402 1410.

[29] S.K. Sharma, T. Dai, G.B. Kharkwal, Y.Y. Huang, L. Huang, V.J. Bil De Arce, G.P. Tegos, M.R. Hamblin, Drug discovery of antimicrobial photosensitizers using animal models, Current Pharmaceutical Design 13 (2011) 1303-1319.

[30] E. Alves, L. Costa, C.M. Carvalho, J.P. Tomé, M.A. Faustino, M.G. Neves, A.C. Tomé, J.A. Cavaleiro, A. Cunha, A. Almeida, Charge effect on the photoinactivation of Gram-negative and Gram-positive bacteria by cationic meso-substituted porphyrins, BMC Microbiolology 9 (2009) 70.

[31] M. Rojkiewicz, G. Zieba, A. Jarczyk, P. Kus, Lipophilicity of tetraarylporphyrins, Part 1. tetra-(hydroxyphenyl)porphyrins with long alkyl chain in the molecule, JPC-Journal of Planar Chromatography-Modern TLC 24 (2011) 201-205.

[32] S. Banfi, E. Caruso, L. Buccafurni, V. Battini, S. Zazzaron, P. Barbieri, V. Orlandi, Antibacterial activity of tetraaryl-porphyrin photosensitizers: an in vitro study on Gram negative and Gram positive bacteria, Journal of Photochemistry and Photobiology B - Biology 85 (2006) 28-38.

[33] S. Banfi, E. Caruso, E. Fieni, L. Buccafurni, M.B. Gariboldi, R. Ravizza, E. Monti, Synthesis and photodynamic activity of diaryl-porphyrins characterized by the presence of nitro groups, Journal of Porphyrins and Phthalocyanines 10 (2006) 1319-1326.

[34] Y. Nitzan, M. Kauffman, Endogenous porphyrin production in bacteria by delta-aminolaevulinic acid and subsequent bacterial photoeradication, Lasers in Medical Science 14 (1999) 269-277.

[35] B. Pudziuvyte, E. Bakiene, R. Bonnett, P.A. Shatunov, M. Magaraggia, G. Jori, Alterations of Escherichia coli envelope as a consequence of photosensitization with tetrakis(N-ethylpyridinium-4-yl)porphyrin tetratosylate, Photochemical \& Photobiological Sciences 10 (2011) 1046-1055.

[36] P.S. Zolfaghari, S. Packer, M. Singer, S.P. Nair, J. Bennett, C. Street, M. Wilson, In vivo killing of Staphylococcus aureus using a light-activated antimicrobial agent, BMC Microbiology 9 (2009).

[37] M.R. Hamblin, T.H. Dai, Can surgical site infections be treated by photodynamic therapy?, Photodiagnosis and Photodynamic Therapy 7 (2010) 134-136

[38] L. Ryskova, V. Buchta, R. Slezak, Photodynamic antimicrobial therapy, Central European Journal of Biology 5 (2010) 400-406.

[39] V.T. Orlandi, E. Caruso, S. Banfi, P. Barbieri, Effect of organic matter on the in vitro photoeradication of Pseudomonas aeruginosa by means of a cationic tetraaryl-porphyrin, Photochemistry and Photobiology 88 (2012) 557-564.

[40] P. Tandon, S. Chhibber, R.H. Reed, Survival and detection of the faecal indicator bacterium Enterococcus faecalis in water stored in traditional vessels, Indian Journal of Medical Research 125 (2007) 557-566.

[41] M. Jemli, Z. Alouini, S. Sabbahi, M. Gueddari, Destruction of fecal bacteria in wastewater by three photosensitizers, Journal of Environmental Monitoring 4 (2002) 511-516. 